\title{
Just war? War games, war crimes and game design
}

lain Donald

This is the accepted manuscript:

Donald, I. 2017. Just war? War games, war crimes and game design. Games and Culture. doi: https://doi.org/10.1177/1555412017720359

Copyright (C) 2017 the author Reprinted by permission of SAGE Publications. 


\begin{abstract}
Military Shooters have explored both historical and modern settings and remain one of the most popular game genres. While the violence of these games has been explored in multiple studies, the study of how war, and the rules of war, are represented is underexplored. The Red Cross has argued that as virtual war games are becoming closer to reality, the rules of war should be included. This paper explores the argument put forward by the Red Cross and its reception by games media organisations, in order to consider how the concept of 'Just War' is represented within games. This paper will focus on concerns over games adherence to the to the criteria of jus in bello (the right conduct in war) and will also consider the challenges that developers face in the creation of entertainment products in the face of publisher and press concerns.
\end{abstract}

Keywords: first-person shooter, just war, war crimes, videogames, game design 


\section{Introduction}

The considerable popularity (Activision, 2013) of first person military-themed shooters (FPMS) has resulted in increasing attention from researchers, non-governmental organisations (NGO’s) and the media on the military-entertainment complex (Halter, 2006). The genre taps into predominantly male audiences' romanticism of the military elite and gun-fetishism. The use of games, such as America's Army, as recruitment tools and simulations also uses this base interest to advance specific goals. Increasingly researchers have deemed it necessary to ask not only how these games portray war but also what effects these might have on the players.

Previous researchers have identified that the wars and conflicts are almost exclusively portrayed from an American or Western perspective (Sisler, 2008; Breuer, Festl, and Quandt, 2011), and tend to naturalize violent intervention, frame the American and Western military as 'just' heroes, and present the regions of conflict and its inhabitants as fundamentally anti-western and terrorist (Van Zwieten, 2011). There are demonstrable trends on the evolution of the genre from the initial surge in games focused around WWII through to those set in modern conflicts to the trend for near-future war (Hoglund, 2014). The genre is now returning to explore historical conflicts, however, the initial shift in focus from creating games depicting the events of past conflicts to those focused in the present or near-future created the sub-genre of Modern Military Shooters (MMS). With the move towards portraying environments recently or currently in conflict, combined with an increasing graphical fidelity and perceived realism, the MMS gained increasing attention from NGOs such as TRIAL, Pro Juventute and the International Committee of the Red Cross (ICRC).

Violent games in general and First-Person Shooters (FPS) more specifically have garnered considerable negative attention in regard to their level of violence, perceived realism 
and the potential impact they may have upon their players (Foulkes, 2013). There has been much less concern regarding the narratives and stereotypes developed within these games or the potential impact that these narratives have in forming opinion on world events. Similarly, whilst the interactive nature of games has led to considerable research on the potential impact that games have on player aggression, there has been less concern over how the moral and ethical decision making within these games shape player's perceptions. Significantly, the position of NGOs is not to prohibit or censor games but rather to request that developers consider the rules of war and do not encourage or glorify their violation without context. When NGOs have raised such concerns, the reaction from the games media and players in general has largely been mirth or outright hostility. There is a need to consider whether NGOs concerns are valid and are feasible for inclusion into game design of these games.

This paper is a result of an ongoing study that examines how war is portrayed in videogames, particularly jus ad bellum (the right to go to war) and jus in bello (the right conduct in war) together with how videogames help contribute to the just war myth (Fiala, 2007). The scope of this study is broad but central to it is how the concept of just war within FPMS can shape the player's perception of right and wrong, and how game narratives based on real-world conflict evolve and reflect public opinion. The study limits the scope by examining FPMS that depict 'armed conflict' or war scenarios from the recent past. Where possible games that mainly portray counter-terrorism, law enforcement style scenarios, or tend towards science-fiction and far-future environments have been excluded from this study. Similarly, though the issues of violence in videogames and the use of games as military recruitment tools are closely linked to this subject, they are not the focus. This paper will consider the arguments put forward by NGOs into developing awareness of International Human Rights Law (IHRL) and International 
Humanitarian Law (IHL) together with those arguments raised by the ICRC. The paper will further explore several themes that have contributed to the controversy e.g. the role of civilians and Private Military Companies (PMCs) in games before outlining some of the design considerations and possible avenues to adhere to IHL. The role of realism and why games are different to films is also discussed.

\section{NGO's and Laws of Armed Conflict}

The popularity of the FPS ensures a steady stream of games in the marketplace. Each developer seeks out an angle in order to compete effectively. Controversies and issues with how FPMS games allow players to behave regularly accompany the advances in the design, realism, immersion, storytelling and gameplay. Recurring concerns over how such games encourage and stimulate aggressive behaviour, or trivialize real-life conflicts and undermine the rules of war have been raised by a number of NGOs. They have argued that the laws of armed conflict should be more accurately reflected within videogames. From the outset the question itself creates controversy for many fans of the genre. On the one hand, it is obvious that these are virtual worlds, immersion can easily be jolted away from the player when players exploit game mechanics to gain an advantage. Game playing techniques such as bunny hopping (using jumping to speed up movement around a map) or dolphin diving (diving to a prone position) quickly remove any perception of real-world simulation. However, real wars and conflicts don't adhere to the laws and monitoring conflicts, recording transgressions and enforcing justice can take years or decades.

The main concerns of the NGOs are detailed in three reports. In 2009, 'Playing by the Rules’ carried out by Track Impunity Always (TRIAL) and Pro Juventute, looked to analyze 
violence in videogames, specifically with the IHRL and IHL in mind. Two years later, the ICRC posted an FAQ detailing the ICRC's mandate to promote respect for IHL, or the 'Law of Armed Conflict'. They further argued that increasingly games represented a realistic simulation on warfare where players are presented with choices that a real soldier could encounter, but often they are not subject to IHL. Finally, in 2012, the ICRC published "Beyond the Call of Duty" which focused on the issue of how modern combat is portrayed in videogames and raised concern that games without the integration of IHL could give the impression that such violations are acceptable. Each report effectively asked the same question: Is there a place for the Laws of Armed Conflict in videogames? With each report building the upon the previous, to develop an argument for greater adherence by developers and publishers.

TRIAL/Pro Juventute stated that its goal in looking at potential war crimes was "not to prohibit the games, to make them less violent or to turn them into IHL or IHRL training tools.” Instead they wanted to focus their message towards developers and publishers to "portray the rules that apply to such conflicts in real life, namely IHRL and IHL.” (TRIAL, 2009). The report also highlighted that the focus on games was a result of the player having an "active role in performing actions” (TRIAL, 2009). In an argument that was to be stressed later by the ICRC, the report described that the boundaries between virtual simulation and real combat were increasingly blurred. Concern therefore stemmed from the theory that players' awareness of the rules of war was being compromised, and that players could potentially believe that breaking the rules of war was acceptable in real combat. The study set out to analyze 30 different game titles. However, several issues regarding the complexity of existing legal frameworks, the conduct of modern conflict and the representation of virtual combat, reduced the number to 20 . The issues remain pertinent in any study. For example, determining whether The Hague Conventions (1899 
and 1907) or Geneva Conventions (1949) applied is dependent upon the game setting. Yet, games can cross multiple time periods, participants and legal definitions. This creates the possibility that some in-game actions are technically outside the application of one of the conventions but not others. Similarly, many MMS depict different forms of combat - from traditional war scenarios, to counter-terrorism and law enforcement operations - and different legal frameworks apply. (TRIAL, 2009). Lastly, some potential violations were at the time controversial or had no clear answer under the legal basis of the time - the role of Private Military Companies (PMC’s) was still largely unclear and rapidly evolving in the real world. Despite these issues, the report identified seven areas where rules of war had been violated in videogames, with three further points to describe violations outside armed conflicts. Amongst the actions that the research team found were:

- Use of a flame-thrower against enemy combatants, classed as a war crime due to causing unnecessary suffering.

- Use of cluster bombs, and 'carpet bombing', covered under indiscriminate attacks and the Convention of Cluster Munitions (2008).

- Treatment of captured or surrendered combatants, including the shooting and killing of injured combatants, torture and execution. All of which are considered under the Geneva Conventions, and violate the passing of sentence and carrying out of execution.

One of the key issues raised was that of distinguishing between civilians and combatants, civilian property and military targets, and their proper treatment. Multiple violations of this Geneva Convention were carried out by the enemies portrayed within the games, often establish a 'just' narrative for the player. TRIAL made the point that all violations of the rules of war have to be considered, whether committed by the player, friendly or enemy non-player characters. Among 
the suggestions that the report made was that developers should avoid creating scenarios that lead to violations of IHL (TRIAL, 2009). This included ‘ticking-bomb' tropes, where a sense of urgency is implied to give the player the impression that using any means necessary is acceptable. Or the use of narratives to create 'just' scenarios for the player. The report further emphasized that games should never suggest that the player can decide what is right and what is wrong, instead that games should reflect the existing legal frameworks. Overall the report raised these concerns and garnered minor press attention, but overall made little impact in the gaming media or community. (BBC, 2009; Cullen, 2009)

Two years later at the 31st International Conference of the Red Cross and Red Crescent a small event took place to discuss the influence of videogames on public perception and action. This was followed by publication of an FAQ detailing the ICRC's position. The original FAQ did garner attention in the games press largely due to two sweeping statements. The first was the suggestion that there was "an audience of approximately 600 million gamers who may be virtually violating IHL,” the second was that potential courses of action included encouraging "governments to adopt laws and regulations to regulate this ever-growing industry." (Crecente, 2011) The unfortunate choice of wording led to the impression amongst some of the gaming media and amongst gamers that the ICRC desired to see IHL represented within games in such a way that they saw violations in games as war crimes. Although the post was quickly updated to stress that serious violations of the laws of war "can only be committed in real-life situations, not in video games” the damage was largely done and undermined the ICRC objective of engaging "in a dialogue with the video gaming industry in order to explore the place of humanitarian rules in games.” (ICRC, 2011) On reflection, the potential of the games press and gamers responding to potential infringements on their pastime was always likely to result in hyperbole. 
Unfortunately, the focus on gamers as war criminals drew attention away from ICRC's mandate to promote respect for IHL, or the 'Law of Armed Conflict'. The FAQ did serve to raise many of the same concerns as TRIAL had in 2009. Notably, that many games represented realistic simulations of warfare and that players were oft-presented with choices that many real soldiers could encounter. Unlike the real military however, their actions were not subject to IHL. It is arguable that the ICRC were aware that critiquing MMS games was an opportunity to raise awareness for IHL, especially given the increasing popularity and size of military games market (American Red Cross 2014, Sigmund 2014). If that was the aim it worked, with both the gaming press and gaming community reporting on and challenging the ICRC's arguments. In particular, the concerns over realism and the players' involvement (even complicity) by playing such games were largely negated. One critic emphasized that despite the improved graphical fidelity of the latest Call of Duty was as realistic as "a Michael Bay action movie”. Another writer aptly summed up the issue "War games are more and more often striving for realism, but that realism is selective”, and stressed that realism “always give way to gameplay” (Fleming 2013).

The ICRC followed up their FAQ with a more formal position paper in 2012. Beyond the Call of Duty focuses on the issue of how modern combat is portrayed in MMS, and argues that without integration of IHL the impression given is that such violations are acceptable. The report begins with a short description of an imagined combat experience within a non-descript MMS. The hypothetical example is used to quickly identify key areas where the rules of war are violated and plays directly to the tropes of the genre. This included artillery swapping between white phosphorus and high explosive shells; the dehumanization and demonization of enemies; excessive use of explosives; collecting of dog-tags; use of land mines; targeting of noncombatants; and execution of wounded enemies (as they unable to surrender or can only be 
captured so they can be tortured for intelligence). The report also identified the use of these violations as mechanics in upgrade systems (particularly in multiplayer), for example rewarding the player for a certain number of kills with weapon or other upgrades. To emphasize the difficulty in separating real from imagined the report placed a screenshot from the game ARMA II alongside real footage from Fallujah. This blurring of truth and fiction, is a core argument for the NGOs. To non-gamers it has become harder to distinguish the visuals of the virtual world from real world. This was further demonstrated when the British TV channel, ITV, was forced to apologize after footage it said was from an IRA propaganda video appeared in a documentary but was later revealed to be from ARMA II (BBC News, 2011). For the ICRC, games that allow the repetition of illegal actions, especially those that result in a reward, have the potential to influence players into thinking that those actions are acceptable. The ICRC is not arguing that violence in games leads to real violence. They are, however, suggesting that repeatedly displaying illegal acts as acceptable will result in an effect on that player's moral and ethical perspective.

FPMS: Influencing or reflecting?

The opposing arguments as to whether, or how, games influence player behavior are ongoing. Yet it is important that games are not taken out of context from other media, or indeed the wider history. The question arises as to whether games are therefore influencing or simply reflecting. MMS games came out post 9/11 and they arguably explore evolving attitudes to the war on terror. One study about what Americans think about violence, particularly torture, in videogames, determined:

"Of the youth surveyed, 59 per cent considered the torture of captured enemy soldiers or fighters in order to extract important military information as acceptable (compared to 51 
per cent of adults). Only 45 per cent and 40 per cent respectively said this conduct was never acceptable” (Clarke, Rouffaer and Senechaud 2012).

It was only in December 2014 that it became public that the CIA had misled Americans regarding the use of torture as part of its Rendition programme. The CIA stated the "intelligence gained from the programme was critical to our understanding of al-Qaeda and continues to inform our counterterrorism efforts to this day.” (BBC World 2014). Although the report surmised that the information failed to directly prevent any attacks, calls for the use of torture remain a continuing point of contention. The ICRC's focus on violations based on the illegal treatment and torture of persons portrayed in games is admirable but arguably games are simply bringing state-sanctioned crimes to the attention of a wider (and harder to reach) audience, thus precisely achieving its aims. The report identifies several other concepts and situations that violate IHL in games:

- Demonization and dehumanization, where enemies are portrayed as evil or fanatical to justify any means used against them. This is further embodied by their inability to surrender when wounded.

- The no penalty concept, where players undertake actions simply because they can, such as shooting civilians. This is directly connected to games removing civilians entirely from their environments, thereby removing the necessity of proper target selection and resulting in a reduction of realism.

- The absence of choice, in that linear narratives can force events upon the player, with no other option given to continue. On occasion, such events are carried out by a friendly character, again preventing choice but also signaling acceptable behavior. 
The report concludes by reiterating that although some MMS pride themselves on realism, or authenticity, most fail to incorporate the rules of war. The main concerns of the NGOs remain that games not only allow violations of IHL and IHRL, they don’t portray the laws at all and some even have reward mechanisms that are directly linked to violations.

\section{Games and the Rules of War}

From the NGO perspective, there are multiple examples of games violating the 'Laws of Armed Conflict'. In the games examined, both by the NGOs and this study, routine violations included torture, destruction of civilian property, direct attacks against civilians, the use of illegal weapons and the shooting of injured or surrendered soldiers. Examples abound and with the number of violations, it is easy to see why NGOs identified MMS as a potential focal point. For example, torture features prominently in games such as Tom Clancy's Splinter Cell: Double Agent (2006) and Call of Duty: Black Ops (2010). Often as part of an interrogation, which may itself be a breach of the law, depending on the status of the prisoner. Prisoners of War should not be pressed to reveal more than their name, rank and military identification (ICRC, 2012). Similarly, civilian property should never be directly targeted and all possible measures should be taken to minimize collateral damage. However, Battlefield 4 (2013) featured destructible buildings, including civilian properties, such as skyscrapers and hydro-electric dams. In Call of Duty 4: Modern Warfare (2007) churches and mosques, explicitly prohibited targets, can be fired upon and destroyed (ICRC, 2012). Several games allow players to target and kill civilians. This goes firmly against the conventions, where it is stated that those who are not involved in the conflict should be protected at all times. In Call of Duty: Modern Warfare 2's (2009) “No Russian” scene, players take part in a terrorist attack at a civilian airport (Warmouth, 2009; 
Totilo, 2012). Scenes in both Spec Ops: The Line (2012) and Metal Gear Solid 4 (2008) also put the player in situations where the option to kill civilians exists (ICRC 2012). One of the core gameplay mechanics in games is to commonly allow prohibited weapons to be used by the player. A weapon is generally prohibited if it causes undue suffering or it detonates on proximity. Ignoring the argument of what weapons don't cause undue suffering, weapons such as cluster bombs have featured in Front Lines: Fuel of War (2008). Clearly, not every game necessarily breaks with all the laws of warfare, but most have instances that do. When these do occur they rarely inform or hinder the player. The scope of games and potential violations that could be explored is wide. To focus on the wider challenges of incorporating IHL into the design and development of games this paper is going to examine three examples the demonstrate the complexity of the problem for NGOs, Publishers/Developers and Gamers. These are the role of PMC's, the role of civilians and the perception of realism.

The Role of PMC’s

The role, growth and evolution of PMC's in Iraq and Afghanistan is complex and still shrouded in mystery. As some writers, have commented they fought a parallel war to the actual armed forces (Fainaru, 2008). As noted by TRIAL in 2009, the status of PMCs remains largely unresolved and both the UK and USA have not signed the International Convention against the Recruitment, Use, Financing and Training of Mercenaries (2001). The complexity of the legal frameworks and largely unmonitored status, combined with the ease with which to invoke interesting narratives ensured that games were at the forefront of representing these entities. They also highlight the challenges of determining whether games can reflect the complex international legal frameworks. For example, Metal Gear Solid 4: Guns of the Patriots (2008) 
was identified in 'Playing by the Rules'. (TRIAL, 2009). The report recognized that the game allows the player to attack and kill incapacitated and wounded enemies. However, such action is not placed in the wider context. Notably at the start of the game the conflict portrayed is one between local militia and an unknown PMC. At this time the player is not allied with the local militia, forcing them to avoid, disable or kill militia members they encounter. After engaging and dispatching soldiers of the PMC - in sight of the militia - they become friendly and even supply aid to the player character. Although the killing of wounded combatants is possible, it is perhaps overlooked because the only negative effect is the hostility of other militia encountered. Few other MMS present the player with this kind of freedom of choice. This freedom extends to allowing for the player to undertake a non-lethal playthrough, through a mixture of stealth and tranquilizer weaponry, and if successful such a playthrough is rewarded with an achievement. Through its narrative MGS4 is one of the few games that attempts to tackle the issue of posttraumatic stress disorder, and the psychological effects of combat. In context, the story allows for the conditioning of soldiers for combat without the years of training and experience that would otherwise be required. However, the removal of the control method results in the complete breakdown of the PMC soldiers. MGS4 is also one of few games that feature PMC's in armed conflict. The use of PMCs in-game is one of the core narrative threads in Call of Duty: Advanced Warfare (2014), and there are interesting historical parallels with games drawing upon the controversy of real-world PMCs such as Blackwater/Academi for storylines. For games the increasing appearance of PMCs provides a useful get-out clause for criticism:

"Unless they are commissioned by governments, private security personnel are not governed by military justice systems. When private security personnel break laws, it is 
not clear how to hold them accountable, particularly where there are weak local institutions.” (Deborah 2005).

The mystique of the mercenary is a trope that games and other media have long used to critique both official and unofficial government policy and to give alternative accounts of war. Their use in games only serves to further demonstrate the complexities of modern warfare and the difficulty of understanding the application of the rules of war in what are by their nature violent and fluid environments. However, games also shine a light on an otherwise largely ignored real world narrative and further demonstrate that game design and development can serve to raise awareness of complex issues.

\section{The Role of Civilians}

Most MMS deliberately avoid incorporating civilians into the game world unless specifically required for the narrative or mission design. From as development perspective this is generally economical. When developers do incorporate civilians' controversy often follows, even when the design explicitly calls for it so the player to face the consequences of their actions. Upon launch, Call of Duty: Modern Warfare 2 (2009), immediately found itself mired in controversy for the level - 'No Russian'. The level depicts a terrorist attack on a Russian airport terminal. The player takes the role of a deep-cover CIA agent, and is presented with the dilemma of playing along with this group of Russian terrorists as they massacre the people within the airport. The designer of the level, Mohammad Alavi, stated that it was not designed with controversy in mind, but to further the plot. As Alavi explained "to sell why Russia would attack the U.S., make the player have an emotional connection to the bad guy Makarov, and do that in a memorable and engaging way.” (Totilo 2012). In Europe, Modern Warfare 2 shipped with the option to skip the first level. In Germany and Japan, the mission was altered to fail upon the 
killing of a single civilian (Warmoth 2009). While undoubtedly courting controversy it is important to note that it is possible to play through this mission without killing a civilian; the terrorists will do that without the player's engagement. Only later, with the arrival of Russian armed forces, do players have to defend themselves. The level then creates another moral dilemma for the player. The player must decide whether killing those attacking is acceptable. It is the 'No Russian' level that is repeatedly used as an example of where games stray toward controversy for controversy’s sake but arguably the level does have a clear narrative and distinctive plotline, and the player can choose not to shoot.

A similar predicament is presented in Spec Ops: The Line (SOTL), a narrative-driven third-person shooter developed by Yager Development. SOTL depicts the breakdown of soldiers within the game world. Unlike MGS4 the soldiers in question are the games protagonists, and their collapses are caused by the direct actions of the player. SOTL is an attempt to demonstrate that games can deal with complicated stories and the situations with which the players are presented are deliberately controversial. Loosely based on Joseph Conrad's Heart of Darkness, a novella that itself remains controversial over a century after its first publication, the scenarios the player faces are all designed to have an emotional impact. Yager were influenced by the 'No Russian’ level (Hamilton, 2012) and set out to create a situation where it was possible for the player to shoot civilians. In one controversial scene three soldiers have become separated, and two find the third being strung up by an angry mob of people. The player shoots the rope and attempts to resuscitate him - but he is dead. Now the angry mob closes in on the remaining two soldiers, seemingly leaving no other option. As the writer Walt Williams explained:

"I know in focus testing there were quite a few people who shot them and didn't mean to or thought that it was the only way to get out of that situation. But also it was designed 
for you to think that. We wanted for you to feel very pressured and not know what to do.” (Hamilton 2012).

Another scenario reveals that a large well-equipped force awaits the player's squad. However, the player's squad have access to a mortar and a stockpile of white phosphorus rounds. If the decision is made to utilize the white phosphorus, your squad mates will complain, “you've seen what this shit does” Lugo (Spec Ops: The Line 2012). After neutralizing the enemy force, the players' squad advances past their burnt bodies. The player comes across a dying soldier, who points further on, revealing the burnt remains of a large group of civilians.

The use of white phosphorus and the fact that the consequences of injuring or killing civilians are deliberately incorporated into the design to advance the overall narrative further demonstrates the complexity of the presenting 'just war'. Arguably SOTL is raising awareness over a controversial weapon in a deliberately provocative scenario. The game was released after the NGO reports but demonstrates the difficulty in incorporating IHL into games. Though not strictly a chemical weapon (and therefore violating the Geneva Protocol and Chemical Weapons Convention), white phosphorus can be considered a breach of Article 35 of Additional Protocol 1 of the Geneva Conventions - by causing unnecessary suffering and or damage to the environment. Designed to produce smoke, or create camouflage, concealment or cover by the military it is largely recognized for its use as a weapon. A mortar barrage tactic employed in Fallujah called "Shake 'n Bake” used white phosphorus rounds alongside regular high explosive rounds to drive targets out of cover to be killed. (Reynolds 2005). It's not an accident that this same scenario was described in the fictitious beginning of Beyond the Call of Duty report. (Clarke, Rouffaer and Senechaud 2012). The decision to use the technique to advance the plot in SOTL further demonstrates developers reflecting actual events. Most MMS choose not to deal 
with the issue of distinguishing between civilians and combatants, or even between civilian property and military targets. The idea of simply removing civilians from the equation limits the potential for controversy but also results in sterile and unrealistic representations of conflict. The ICRC believes this turns the portrayal of the war-zone into a law-free zone, populated only by targets. Yet from a development perspective adding civilians, crowds, potentially children and dealing with the associated tasks (character modelling, rigging, animation and AI behaviors) is resource intensive for minimal benefit. Such features are likely to be cut even if planned in the initial development schedule. Here lies the development dilemma, to what end does the recreation of a virtual conflict zone need to be achieved to satisfy authenticity and pseudorealism in an entertainment product?

Perceived Realism and the MMS

The pursuit of authenticity and realism in these games was a primary concern of the NGOs, and that in not adhering to the 'rules of war' was inadvertently educating players that violations were acceptable. Evidently there are lines as to what realism is acceptable and where these lines become blurred there are potential repercussions for the genre and the game industry. The best example of this is a game that was not made, Six Days in Fallujah (SDIF). SDIF is an unreleased third-person shooter that was being developed by Atomic Games, but was cancelled largely due to the controversy of making a game based on a real event (Parker 2012). Atomic Games had been working with the United States Marine Corps (USMC) to create a 'real-time tactical war game'. This involved the USMC assigning Marines recently returned from fighting in Iraq to aid Atomic.

“As Marines came and went, the same faces began to pop up again and again, until eventually Atomic development staff found themselves working with a core group of 
about a dozen Marines, most of them from the 3/1 unit (a battalion-level infantry and support personnel unit). Despite the fact that the group only met twice a year, friendships formed easily.” (Parker 2012).

The marines' unit was then deployed in Fallujah, and although all the known members returned, it was discovered that more than 40 percent of their battalion had been wounded or killed. After some of the marines expressed an interest in re-creating their experiences in Fallujah, the development of SDIF began, with the intention of creating a fully destructible urban environment to tell the story of each soldier's experiences (Matos 2010). The game was described as a 'documentary-style game’ portraying the actions of the allied forces that fought at Fallujah. It was this ambition that has ensured that a game, that was never made, has become a significant example of the challenge of authenticity in videogames and MMS in particular. On the one hand the working relationship between the USMC and Atomic Games and the emphasis on documentary speaks of the creation of a game representing the realities of actual combat. On the other hand, the almost inevitable backlash for tackling such a recent and devastating battle resulted in the game being cancelled before it ever entered production. Given the notoriety that the Battle of Fallujah gained and the significant numbers of US forces wounded or killed and the much larger estimates of insurgent and civilian casualties, it seems that Atomic had not prepared for the incoming attention and controversy. Yet at the same time it raises questions as to why other media, such as film and television, can broach the same subject without the same level of controversy. What is it that makes a documentary-style game so unpalatable to non-gamers? Indeed, exploring the maturity of games to deal with subjects such as commemoration is a significant barrier to acceptance as a mature medium. When is the pursuit of realistic, too real? 
The idea of 'realism' is a recurring element in any study of MMS. The perceived realism in these games is one of the main reasons why the ICRC is seeking for them to adhere to the rules of war. However, a gamer or non-military perspective is arguably different from those that have witnessed or experienced combat. The ICRC has raised the concern that in many MMS games the game world creates a perception that battlefields are void of the rules of war, and it is argued that this view is one that influences potential recruits and military personnel who play them. However, from the limited evidence available, veterans who have experienced real combat would indicate that realism is not a primary concern, motivator or interest for them in games.

- "I use those games as - well, to blow off steam.” (Clark 2013).

- “It's like a cartoon version of reality — it lets you work out aggression and build handeye coordination at the same time.” (Lomberg and Mull 2012).

When asked why they play these types of games, the responses are similar. Military personnel are quick to point out inaccuracies in equipment and gear featured in such games, and are also quick to dismiss them as they are 'just games'. One major recurring theme when asked about the games portrayal of a soldier is the rejection of the 'lone wolf', or 'one-man-army' depictions found in a large number of MMS. They are quick to point out inadequate AI squad mates, and the juxtaposition with the importance of teamwork in the real world.

With regards to the ICRC's concern about gamers who may join the military, having a flawed view of actual combat, military personnel have stated similar comments regarding the fact that games cannot help anyone prepare for war or understand what they will encounter (Thang 2012, Clark 2013). A concern that military personnel do have, is that people who have not seen actual combat may actually believe they have some understanding of the reality of war from playing games. One Staff Sergeant stated there is no MMS that can express "post-traumatic 
stress disorder, innocent casualties, the feeling of your friends being injured or killed, the feeling of a real threat of a person trying to kill you” (Thang 2012). Perhaps some of the most revealing reflections on the concerns over realism in games is Josh Bricker's Post Newtonianism that takes a mission from Call of Duty: Modern Warfare - 'Death from Above', where the player takes control of the gunner of an AC-130 gunship. When played alongside some actual AC-130 gunship camera footage, with real audio, it is difficult for the non-gamer and the non-military personnel to determine which is real and which is simulated (Bricker 2010). The main reason that this small section of gameplay represents one of the most authentic portrayals to date is that it is:

“Presented solely in grainy, low-fi, 'white' or 'black hot' night vision, its lack of visual polish has the seemingly counter-intuitive effect of bringing it utterly in line with the real-life footage we've all seen.” (Burns 2014).

The visuals combined with simple radio comments like "woah!”, “ka-boom”, 'Death from Above' is worryingly close the real thing. Arguably, if there are concerns over whether MMS games are truly blurring the lines between simulation and reality, then a detailed study of footage from soldiers' helmet cameras - providing an almost first-person like perspective - should be examined. While the focus would inevitably lean towards combat, the reality of frontline soldiers' days, weeks, months, and tours may help persuade millions of 'kids' that have grown up on Call of Duty and Battlefield that they still don’t know “modern warfare” (Plunkett 2012). While games portray many aspects of war that concern NGOs, the similarity between mainstream shooters like Modern Warfare 2 and action films also needs to be addressed. That both are paced out as distinct pieces of entertainment, providing a steady stream of set pieces and constant action that is far removed from real combat is one aspect. Another is that both 
commonly use military advisers to validate arguments for authenticity and realism. The ICRC has gone as far as to state that the perception of war and war crimes is shaped both by games and films. However, it is important to note that this realism is selective: today game simulations, such as ARMA III, are more than complex enough to realistically represent the characteristics of the weapons recreated in them. Yet due to certain perceptions of how such weapons work in movies - like a shotgun being a powerful close-range weapon - it’s the in-game design characteristics that are altered to match this perception. “The reason for scaling back on realism isn't the hardware, but the drive to make guns feel like the ones we've seen in movies.” (Sofge 2008). Film is not devoid of criticism either. The Hurt Locker (2008) won six Oscars and whilst undoubtedly a successful film, it also received criticism for its numerous inaccuracies in portraying the U.S. military in Iraq. Both Hoit and Reickhoff (2010) cite inaccuracies in the gear and uniforms shown, which should have been relatively easy to research. More interestingly both criticize the depiction of the Explosive Ordnance Disposal (EOD) team within the film.

Criticisms include familiar themes of the lone wolf (an EOD team would never be sent out alone without support), lack of communication seemingly isolating the team, and the fact that the film's main character would be exactly the wrong type of person to lead such a team. The Hurt Locker, much like many games mentioned here, tackles some difficult issues within armed conflict. At least two scenes depict the killing of captured insurgents, one wounded insurgent is denied medical treatment, and possibly executed. Later two prisoners of war (who are bound and hooded), are gunned down while attempting to flee by what appears to be British mercenaries. There is a clear link between war films and the MMS genre, looking at the direction and locations of games compared to major films that came before them. Yet war films thus far have not received the same attention as MMS in regards to their portrayals of combat. This leaves the 
main difference of a player's active role and choices within a game as the only point of difference, and the reason why games are treated differently.

\section{Designing for IHL}

The current phase for MMS is seeing the genre move away from current or recent conflicts towards near-future or century-past scenarios. While this helps fictionalize the narratives and move away from debates about what is 'allowed' and 'not allowed' in games there is an argument that game developers and publishers could reinvigorate the genre by taking on board some of the NGOs suggestions by increasing realism. There are several key areas that could enhance both the game from a player standpoint and work towards meeting the NGOs concerns.

Player Choice - although difficult to achieve, as the artificial environment created must have certain boundaries and rules. Used correctly, improved player choice can be a powerful tool to both avoid and violate the rules of war. Giving the player the option to choose the outcome they deem necessary can be used as a method to teach the consequences of that action. Similarly, the removal of choice is equally as powerful and there are undoubtedly certain actions that cannot be permitted. Care must be taken to not avoid showing an action as a violation of the rules of war, by not allowing the player to take such action. Similarly, attention must be taken when potentially forcing an action that results in a violation upon the player, with no other options.

Violations of IHRL and IHL - arguably a violation of the 'rules of war' may be required, either through gameplay or narrative. In doing so the player should be made to consider why such a violation is necessary, and how it can be handled correctly. Violations can and should be 
properly considered where involving - the player, friendly non-player characters and enemy characters. Most importantly, for every violation that can occur - there must be an appropriate consequence.

Civilians - In the past the issue of targeting of civilians has been commonly tackled by their removal from the game environment. Though there are possible scenarios where the civilian population is not present, this cannot always be the case. The addition of civilians within an environment forces the player to distinguish between civilians and combatants, and avoids the creation of a zone populated only by targets. Consequences of targeting civilians should be included, ranging from outright mission failure for deliberate violations, to other built in mechanisms such as reputation or trust loss for accidental violations.

Enemies - Opponents in MMS often lack the range of abilities that should be available to them. Wounding of enemies is not a common occurrence, and they often will attempt to continue to fight. The option for an enemy character to surrender, whether being out of ammunition, surrounded or wounded should be possible. In the case of surrender, the player could be able to restrain healthy combatants, or supply medical attention to those who are wounded. This would largely require an increased focus on disempowerment mechanics but could open new game modes. The demonization and/or dehumanization of enemy characters should be avoided as far as possible. Having enemy characters commit violations simply to label them as 'evil' is relative cheap and encourages the idea that the player can then use 'any means necessary' to defeat them. The bodies of fallen combatants should be respected (whether in single or multiplayer). Equally it is not acceptable to portray the act of trophy taking, such as dog tag collection from fallen combatants. 
Environmental Destruction - A recurring violation is that of unnecessary levels of destruction of civilian property. Though in conflict damage to civilian property will occur, often little or no limitations are imposed upon the player. Targeting of structures of cultural or religious significance should not be permitted. Environments are becoming ever more destructible in MMS, therefore after reaching a certain threshold - a consequence could be triggered. The scale of the destruction could be factored in, with minor damage slowly accumulating, and major damage (like destroying a large building) possibly ending the mission straight away.

Use of Forbidden Weaponry - Care must be taken when depicting the use of forbidden weaponry. This includes both those that are illegal (such as chemical weapons) and those which may not strictly be illegal, but can be used in such a way that they would be in violation like white phosphorus (Reynolds, 2005). Use of indiscriminate weapons, such as cluster bombs or land mines should only be depicted, with the consequences of such actions.

While these potential changes impact significantly on development, the adoption of IHL and IHRL, into games could provide real-world constraints for designers and developers to explore. The moral and ethical implications for designers to interpret, recreate and consider the impact of, may result in more interesting narratives and deviations from established mechanics.

\section{Conclusion}

The MMS genre remains hugely popular and as long as the genre continues to enjoy commercial success, games will continue to attract the attention and criticism of NGO's and the mainstream media. Increasingly different forms of war games such as Valiant Hearts and This War of Mine are finding commercial success. Some developers such as Bohemia Interactive and 
their ARMA series have already engaged with the ICRC to improve design. However, further research into the portrayal of the moral and ethical complexities of conflict and the modern battlefield would help more developers and publishers embrace the challenges of designing games acknowledging the rules of war. If more games can place the player in situations where the moral and ethical implications of each decision are demonstrable, it could reinvigorate the genre with more interesting narratives, gameplay mechanics and greater immersion. Although games in the genre are often marketed as realistic and authentic in terms of the equipment and environmental accuracy, the Modern Military Shooter remains a long way from evoking emotions and feelings that define accounts of combat in other media. Improving player choice, considering rules of engagement and informing players of violations to IHRL and IHL arguably create more engaging narratives and gameplay. For a more significant change of direction major studios and publishers need to engage with NGOs and should consider the potential benefits and design challenges that added 'realism' may bring to the genre. 


\section{References}

11 bit studios (2014) This War of Mine. [PC]. 11 bit studios. Warsaw, Poland.

2K Games (2012) Spec Ops: The Line. [Xbox 360]. Yager Development. Berlin.

Activision (2007) Call of Duty 4: Modern Warfare. [Xbox 360]. Infinity Ward. Woodland Hills, Los Angeles USA.

Activision (2009) Call of Duty: Modern Warfare 2. [Xbox 360]. Infinity Ward. Woodland Hills, Los Angeles USA.

Activision (2014) Call of Duty: Advanced Warfare. [Xbox 360] Sledgehammer Games. Foster City, California, USA.

Activision (2008) Call of Duty: World at War [Xbox 360] Treyarch. Santa Monica, California, USA.

Activision (2010) Call of Duty: Black Ops. [Xbox 360] Treyarch. Santa Monica, California, USA.

Activision (2013). “Call of duty - by the numbers.” Retrieved December 15, 2016, from https://community.callofduty.com/community/call_of_duty/english/ghosts/blog/2013/08/ 13/call-of-duty-by-the-numbers

American Red Cross (2014). “Targeting the laws of war with video games.” in American Society of International Law. Retrieved November 23, 2016, from http://www.asil.org/targetinglaws-war-video-games

A/RES/44/34. International Convention against the Recruitment, Use, Financing and Training of Mercenaries. (1989, December 4). Retrieved December 18, 2015, from http://www.un.org/documents/ga/res/44/a44r034.htm

Bohemia Interactive (2009) ARMA II. [PC]. Bohemia Interactive. Prague. Czech Republic. 
Bohemia Interactive (2013) ARMA III. [PC]. Bohemia Interactive. Prague. Czech Republic.

BBC News. “Games 'permit' virtual war crimes”. Retrieved November 15, 2016, from http://news.bbc.co.uk/1/hi/technology/8373794.stm

BBC News “ITV documentary in IRA computer game blunder.” Retrieved January 18, 2016, from http://www.bbc.co.uk/news/uk-northern-ireland-15082177

BBC World (2014). “Report on CIA details 'brutal’ post-9/11 interrogations.” Retrieved December 9, 2015, from http://www.bbc.co.uk/news/world-us-canada-30401100/

Bricker, J. (2010). “Web biennial 2012 - Josh Bricker - Post Newtonianism (war footage/call of duty 4 modern warfare).” Retrieved December 16, 2015 from https://www.youtube.com/watch?v=-cto649nkjY/

Breuer, J., Festl, R. and Quandt, T., (2011). “In the army now - Narrative elements and realism in military first-person shooters.” DiGRA. (Utrecht Netherlands, September 2011).

Burns, S. (2014). "Death From Above: How COD4 is the most realistic war game ever made.” Retrieved December 27, 2015, from http://www.videogamer.com/pc/call_of_duty_4_modern_warfare/features/article/death_fr om_above_how_cod4_is_the_most_realistic_war_game_ever_made.html/

Chemical Weapons Convention (1997). “Convention on the Prohibition of the Development, Production, Stockpiling and Use of Chemical Weapons and on their Destruction” Retrieved October 15, 2015, from https://www.icrc.org/ihl/INTRO/553?OpenDocument Clark, M. (2013) “What do men who’ve answered the real call of duty think about military games?” Retrieved December 9, 2015, from http://www.digitaltrends.com/gaming/whatdo-men-whove-answered-the-real-call-of-duty-think-about-military-games/ 
Clarke, B., Rouffaer, C. and Senechaud, F. (2012). "Beyond the call of duty: why shouldn't video game players face the same dilemmas as real soldiers?” International Review of the Red Cross. Vol 94(1): pp. 711-737.

Convention on Cluster Munitions (2008). Retrieved October 15, 2015, from https://www.icrc.org/ihl/INTRO/620

Crecente, B. (2011) “War crimes in video games draw Red Cross scrutiny.” Retrieved September 23, 2015, from http://kotaku.com/5863817/war-crimes-in-video-games-draw-red-crossscrutiny

Crecente, B. (2011) “It’s time for a war game that respects the Geneva conventions.” Retrieved September 23, 2015, from http://kotaku.com/5865042/its-time-for-a-war-game-thatrespects-the-geneva-conventions

Crecente, B. (2011) “Red Cross won’t go after you for playing war games,” Retrieved September 23, 2015, http://kotaku.com/5866359/red-cross-wont-go-after-you-for-playing-wargames

Crecente, B. (2013) "Why the Red Cross cares how video games treat war crimes.” Retrieved October 3, 2015, from http://www.polygon.com/2013/10/7/4812356/why-the-red-crosscares-how-video-games-treat-war-crimes

Cullen, J. (2009). “Games let you commit ‘violations of international law,' says human rights groups”. Retrieved January 15, 2016, from https://www.vg247.com/2009/11/23/gameslet-you-commit-violations-of-international-law-says-human-rights-groups

Deborah, D. A. (2005) “Private military companies and the future of war.” Retrieved December 8, 2015, from http://www.fpri.org/articles/2006/04/private-military-companies.

Electronic Arts (2010) Battlefield 4. [Xbox 360]. EA DICE, Stockholm, Sweden. 
Fainaru, S. (2010). Big Boy Rules. Da Capo, Cambridge, Massachusetts

Fiala, A. G. (2008) The Just War Myth: The Moral Illusions of War. Rowman \& Littlefield, Lanham, Maryland.

Fleming, R. (2013) “Gamed: video games and the laws of war.” Retrieved December 18, 2015, from http://www.digitaltrends.com/gaming/gamed-video-games-and-the-laws-of-war/

Foulkes, I. (2013) “Should the rules of war be included in computer games?” Retrieved July 3, 2015, from http://www.bbc.co.uk/news/technology-24318061

Geneva Conventions (1949) "First, Second, Third and Fourth Geneva Conventions. 1949, Additional Protocols I, II 1977 \& III 2005.” Retrieved October 3, 2015, from https://www.icrc.org/en/war-and-law/treaties-customary-law/geneva-conventions

Geneva Protocol (1925) "Protocol for the Prohibition of the Use of Asphyxiating, Poisonous or Other Gases, and of Bacteriological Methods of Warfare. Geneva, 17 June 1925” Retrieved October 6, 2015, from https://www.icrc.org/applic/ihl/ihl.nsf/Treaty.xsp?action=openDocument\&documentId=9 21B4414B13E58B8C12563CD002D693B

Halter, E. (2006) From Sun Tzu to XBox: War and Video Games. Thunder's Mouth Press, New York.

Hamilton, K. (2012) “How to kill civilians in a war game.” Retrieved December 10, 2015, from http://kotaku.com/5928765/how-to-kill-civilians-in-a-war-game

Hoglund, J. (2014). “IR and the Future Wars of First Person Military Shooters.” Retrieved December 9, 2015, from http://www.e-ir.info/2014/10/09/ir-and-the-future-wars-of-firstperson-military-shooters 
Hoit, K. (2010). “The hurt locker doesn’t get this vet’s vote.” Retrieved November 16, 2015, htttp://www.huffingtonpost.com/kate-hoit/the-hurt-locker-doesnt-ge_b_449043.html

International Committee of the Red Cross. (2011). "Is there a place for the laws of armed conflict in video games?” Retrieved December 31, 2015, from https://www.icrc.org/eng/resources/documents/faq/ihl-video-games-faq-2011-12-08.htm International Committee of the Red Cross. (2013). "Video games and law of war," Retrieved November 3, 2015, from https://www.icrc.org/eng/resources/documents/film/2013/09-28ihl-video-games.htm

Konami (n.d.) Six Days in Fallujah. [TBA]. Atomic Games. Minneapolis, USA.

Konami (2008) Metal Gear Solid 4: Guns of the Patriots. [Playstation 3]. Kojima Productions. Tokyo, Japan.

Lomberg, J. and Mull, D. (2012). “A soldier’s perspective on call of duty and its ilk.” Retrieved December 4, 2015, from http://venturebeat.com/2012/11/24/gamesbeat-discusses-firstperson-shooters-with-a-combat-vet/

Matos, X. (2010). "Status update: six days in Fallujah, with atomic games president Peter Tamte.” Retrieved December 6, 2015, from http://www.engadget.com/2010/03/31/statusupdate-six-days-in-fallujah-with-atomic-games-president/

Parker, L. (2012). “Six days in Fallujah: the untold story.” Retrieved December 8, 2015, from http://www.gamespot.com/articles/six-days-in-fallujah-the-untold-story/1100-6396567/

Plunkett, L. (2012). “Forget call of duty, this is what real war looks like.” Retrieved December 15, 2015, from http://kotaku.com/5947161/forget-call-of-duty-this-is-what-real-warlooks-like/ 
Reickhoff, P. (2010) “Veterans: why ‘the hurt locker’ isn’t reality.” Retrieved December 15, 2015, from http://www.newsweek.com/veterans-why-hurt-locker-isnt-reality-75205

Reynolds, P. (2005) “White phosphorus: weapon on the edge.” Retrieved December 8, 2015, from http://news.bbc.co.uk/1/hi/world/americas/4442988.stm

Sigmund, C.E. (2014) “Learning the rules of war from video games.” Retrieved January 26, 2016, from http://intercrossblog.icrc.org/blog/learning-the-rules-of-war-from-videogames

Šisler, V. (2008) ‘Digital Arabs: Representation in Video Games’ in European Journal of Cultural Studies. Vol. 11, No. 2, 2008, pp. 203-220

Sofge, E. (2008) “Shooting for realism: how accurate are video-game weapons?” Retrieved December 8, 2015, from http://www.popularmechanics.com/technology/gadgets/videogames/4255750

Thang, J. (2012). “What do real soldiers think of shooting games?” Retrieved December 11, 2015, from http://uk.ign.com/articles/2012/02/23/what-do-real-soldiers-think-ofshooting-games

The Hague Conventions of 1899 and 1907, I - XIV. Retrieved December 18, 2015, from https://www.icrc.org/applic/ihl/ihl.nsf/vwTreatiesByDate.xsp

The Hurt Locker (2008). Directed by Kathryn Bigelow. Voltage Pictures, Grosvenor Park Media, Film Capital Europe, Funds, First Light Production, Kingsgate Films and Summit Entertainment.

THQ (2008) Frontlines: Fuel of War. [Xbox360]. Kaos Studios New York, NY, USA. 
Totilo, S. (2012). “The designer of call of duty’s ‘no russian’ massacre wanted you to feel something.” Retrieved December 3, 2015, from http://kotaku.com/5931235/the-designerof-call-of-dutys-no-russian-massacre-wanted-you-to-feel-something/

Track Impunity Always (TRIAL). and Pro Juventute. (2009) "Playing by the rules: applying international humanitarian law to video and computer games.” Retrieved November 19, 2016, from https://trialinternational.org/latest-post/are-war-games-free-of-rules-a-reportby-trial-and-pro-juventute/

Ubisoft (2006) Tom Clancy’s Splinter Cell: Double Agent. [Xbox360]. Ubisoft Shanghai. Shanghai, China.

Ubisoft (2014) Valiant Hearts: The Great War. 2014. [iOS]. Ubisoft Montpellier. Montpellier, France.

United States Army (2002) America’s Army. [PC]. United States Army, Washington D.C., USA. van Zwieten, M. (2011). “Danger Close: Contesting Ideologies and Contemporary Military Conflict in First-Person Shooters,” DiGRA. (Utrecht Netherlands, September 2011). Warmoth, B. (2009) "No Russian scene censored for call of duty modern warfare 2 in Japan.” Retrieved December 6, 2015, from http://multiplayerblog.mtv.com/2009/12/09/norussian-scene-censored-for-call-of-duty-modern-warfare-2-in-japan/ 